\title{
Correction to: Factors controlling the migration phenology of Siberian Phylloscopus species
}

\author{
László Bozó ${ }^{1}$ · $\cdot$ Tibor Csörgö² - Wieland Heim ${ }^{3}$
}

Published online: 17 March 2021

(c) The Author(s) 2021

\section{Correction to: Journal of Ornithology (2021) 162:53-59 https://doi.org/10.1007/s10336-020-01805-5}

In the original publication of the article, Table 1 was published with an error. Authors found that wrong values were given in the last two columns (the start and the end date of the spring migration period instead of the length of the migration periods in spring and in autumn).

The correct Table 1 is given in this correction.

\section{László Bozó}

bozolaszlo91@gmail.com

1 Department of Systematic Zoology and Ecology,

Eötvös Loránd University, Pázmány Péter sétány 1/C,

1117 Budapest, Hungary

2 Department of Anatomy, Cell- and Developmental Biology,

Eötvös Loránd University, Pázmány Péter sétány 1/C,

1117 Budapest, Hungary

3 Institute of Landscape Ecology, University of Münster, Heisenbergstraße 2, 48149 Münster, Germany 
Table 1 The number of trapped individuals, the median migration dates and the length of the migration periods of the seven study species

\begin{tabular}{|c|c|c|c|c|c|c|c|c|}
\hline \multirow[t]{2}{*}{ Species } & \multicolumn{2}{|l|}{ Spring } & \multicolumn{2}{|l|}{ Autumn } & \multicolumn{2}{|c|}{ Median date } & \multicolumn{2}{|c|}{$\begin{array}{l}\text { Length of migration } \\
\text { period (days) }\end{array}$} \\
\hline & Standard & Non-standard & Standard & Non-standard & Spring & Autumn & Spring & Autumn \\
\hline P. inornatus & 2048 & 338 & 1718 & 603 & 14 May & $7 \mathrm{Sep}$ & 42 & 73 \\
\hline P. borealis & 202 & 38 & 183 & 47 & 27 May & 23 Aug & 22 & 47 \\
\hline P. plumbeitarsus & 57 & 8 & 114 & 33 & 31 May & 27 Aug & 22 & 56 \\
\hline P. tenellipes & 30 & 11 & 146 & 45 & 19 May & 15 Aug & 21 & 34 \\
\hline P. fuscatus & 749 & 154 & 1328 & 522 & 21 May & $7 \mathrm{Sep}$ & 41 & 71 \\
\hline P. schwarzi & 96 & 7 & 191 & 62 & 25 May & 11 Sep & 32 & 60 \\
\hline P. proregulus & 72 & 11 & 276 & 122 & 22 May & $25 \mathrm{Sep}$ & 38 & 42 \\
\hline
\end{tabular}

Numbers are shown separately for birds trapped in standard mist-nets (used in all study years) and for birds trapped in non-standard nets (not used in all study years)

Publisher's Note Springer Nature remains neutral with regard to jurisdictional claims in published maps and institutional affiliations. 